\title{
Universiti Kebangsaan Malaysia Learning Contract Course: Experience and Performance of the First Cohort
}

\author{
Adi Irfan Che Ani ${ }^{1,2}$, Norngainy Mohd Tawil ${ }^{2}$, Suhana Johar ${ }^{2}$, Khaidzir Ismail ${ }^{1} \&$ Mohd Zulhanif Abd Razak ${ }^{2}$ \\ ${ }^{1}$ Centre for Learning Accreditation, The National University of Malaysia, Bangi, Selangor, Malaysia \\ ${ }^{2}$ Department of Architecture, Faculty of Engineering and Built Environment, The National University of \\ Malaysia, Bangi, Selangor, Malaysia \\ Correspondence: Adi Irfan Che Ani, Centre for Learning Accreditation, The National University of Malaysia, \\ Bangi, Selangor, Malaysia. E-mail: adiirfan@gmail.com
}

Received: August 19, 2013 Accepted: October 15, 2013 Online Published: January 12, 2014

doi:10.5539/ies.v7n2p1 URL: http://dx.doi.org/10.5539/ies.v7n2p1

\begin{abstract}
Research from different parts of the world recognizes the effectiveness of a learning contract course in improving the personal skills of students. Therefore, UKM has chosen this approach to improve the personal soft skills of its students. The university has carried out this approach by making HHHC9118-Soft Skills as a compulsory course for all students. This course requires the students to implement a project or activity in accordance with a written contract that they plan together with their instructors. Moreover, the students are awarded with eight credit hours after taking up this course. This research evaluated the effectiveness of the learning contract course in developing the soft skills of the 2,378 participants, who had already finished the course. A literature review and a survey were conducted to obtain the data. The questionnaire contained 10 statements, which were either positive or negative, that asked about the self-esteem levels of the respondents. Data were analyzed using the Statistical Package for Social Science (SPSS) software. The results showed the respondents positively interpreted all the statements in the questionnaire, which proved that a learning contract successfully improved the soft skills and self-esteem of UKM students. Therefore, this approach effectively improved the soft skills of the students.
\end{abstract}

Keywords: learning contract, soft skills, students, university, Malaysia

\section{Introduction}

The increase in the number of graduates from local and foreign universities creates an intensely competitive atmosphere among jobseekers, especially among those who are aiming for the most popular jobs. Such intensity increases every year, unlike many years ago when fresh graduates can easily secure a decent job and receive plenty of job offers from employers. This situation has changed completely nowadays, given that most graduates have to work hard to secure a job, even if they possess a degree or any high-level educational certificate. Some graduates have to work part-time while waiting to secure a more stable job. Some of these graduates have to wait for many years to achieve their desired job. Moreover, some graduates work in areas that are far from their university degrees.

This situation has occurred because the number of graduates is higher compared to the number of available jobs. These graduates have to compete with each other to secure their desired jobs. Their academic qualifications are only useful during the screening stage of their job application, which is usually conducted by employers to filter a large number of job applicants. After they have passed the academic screening, the candidates proceed to the interview stage, in which their academic qualifications can no longer determine their chances of passing their application. The candidates can only rely on their soft skills to pass the application stage.

Soft skills are very important in the job-seeking competition. Employers not only seek applicants with outstanding academic achievements, but they also look for applicants who are certain to excel in their jobs and to contribute greatly to the organization. An ideal employee must have diligence, independence, effective communication skills, team spirit, strong leadership skills, creativity, and critical thinking, among others. These features are part of their soft skills.

Graduates develop their soft skills through actual experience and practices. Therefore, UKM has developed a 
course that utilizes a learning contract as a graduation requirement. This course requires students to plan activities or projects under the supervision of their lecturers. The students must also implement their projects, which can be done usually within a group. The lecturers evaluate and grade the success of such projects. By implementing their projects, the students experience and manage an activity, which enhance their soft skills in various aspects. This paper discusses about the first cohort experience and the performance of UKM students who have completed the eight credit hours of the course.

\section{Literature Review}

A learning contract is a document developed by the students and instructors based on what teachers can teach, what agencies and institutions expect, and what students want to learn (Bogo \& Vayda, 1998). Boak (1998) defines the learning contract as a written agreement between a student and a tutor about what students will learn and how they will be evaluated. Neary (2000) states that a learning contract is designed by lecturers and students to determine what the students will learn, how it will be accomplished, how long the project will take, and how it will be evaluated. McCabe (2008) defines the learning contract as a written agreement between the student and the instructor in which the students agree to complete their assignments or projects within an agreed time. Selamat et al. (2011) define the learning contract as a set of activities that enable the students to consult with their teachers, individually or in small groups, to determine their activities, learning outcomes, strategies, and resources they need to achieve their goal. UKM defines the learning contract as a mutual agreement between the students and the lecturers regarding the activities or projects to be planned and implemented to meet the required eight credit hours and the eight predetermined outcomes. These projects are organized based on mutual trust and honesty.

Upon reaching an agreement, the student and the lecturer sign a written agreement (Sweitzer \& King, 2008). The learning contract must have features that qualify the students to receive academic credit (Anderson, 1994). The learning contract aims to enhance the values, knowledge, and skills of the students (Horejsi \& Garthwait, 2002). However, the success of the learning contract in the university setting can be affected by two factors, namely, the support from the academic faculty and the dissemination of theory-based knowledge before the implementation of programs and activities (Tuohy \& Bailey, 2009). The importance and influence of learning contracts on the students have prompted UKM to make this course compulsory in 2012.

After reaching an agreement with their lecturers, the students proceed with their tasks based on the contract. The students become responsible for their learning process because they are directly enforcing their contract (Freedberg, 1989; Anderson et al., 1994; Cross, 1996). In addition, Lemieux (2001) states that through this contract, the students are able to decide personally, and therefore, are responsible for their learning experience. The students also choose activities or projects according to their interest and convenience (Knowles, 1986; Stewart-David, 1993). According to Knowles (1990), adults learn best in comfortable and non-threatening conditions.

The assignments in the learning contract can be accomplished individually or in groups, and depend on the consensus and conformity of students to the tasks. Brewer et al. (2007) reveal that each student can perform different activities or levels within the same project. The learning process is better done in a group than individually because team activities can increase student participation in the learning process by sharing their ideas and responding to their colleagues (Chickering \& Gamson, 1991). Therefore, a learning contract can improve self-confidence, motivation, knowledge, and relations among students (Stewart-David, 1993). The students who take this course develop intellectual freedom and the ability to determine the direction of their learning (Savery \& Duffy, 1994; Boak, 1998). Savery and Duffy (1994) explain that the planned projects encourage students to create their own knowledge when solving complex problems. Clarifying the objectives of learning contracts can bridge the gap between practice and theory, and can demonstrate the transfer of knowledge into practice (Rolfe, 1996). Learning contracts can effectively empower students to manage their own learning. This method has been recognized around the world for many years (Knowles, 1986).

Learning methods serve as a medium for the students to fulfill their ambitions and to enhance their creativity and ability. This course can be used as a platform for students to expand their interests and talents, which may be limited within a specific curriculum (Mahoney et al., 2003; Jamaluddin et al., 2009; Canham \& Bennett, 2002). The students and teachers are free to design any activity in accordance with the objectives and standards (Neary, 2000). Diverse activities provide several opportunities for the students to learn what they cannot learn inside their classrooms.

Selamat et al. (2011) find that the involvement of students in various activities provides them with useful experience because these activities expose them to the outside world, where they will face the true nature and the 
challenges in their work. The authors add that the students enhance the value of their knowledge by applying it practically in their activities rather than by just passing their exams (Selamat et al., 2011). Hussain et al. (2008) indicate that passive learning hinders the effectivity of the learning process and mastery of soft skills. As an active learning process, a learning contract breaks the passive learning tradition that is practiced in most education systems (Hardigan, 1994). Moreover, an active student usually becomes more successful than a passive student (Tornyay \& Thompson, 1987).

According to McAllister (1996), the learning contract helps in the self-study process, which is specific to the needs of the students. Lemieux (2001) finds that the learning contract can effectively enhance the sense of responsibility and academic performance. Kuh et al. (2006), Jamaluddin et al. (2009), and Mulder (2009) claim the success of students in the university depends on their participation in academic and social activities. The learning contract implements both the academic and social approaches.

The experience gained from the activity can help students improve their personality (Selamat et al., 2010). Moreover, human interactions increase the need for students to develop good personalities. Learning contracts are widely used in various areas of education (Brockett \& Heimstra, 1991; Selamat et al., 2011) to motivate students to manage their own learning process (Knowles, 1986).

Theoretically, universities use learning contracts to enhance the soft skills of their students. Brecko (2003), Johnston and Watson (2004), and Hermens and Clarke (2009) claim that students who have taken this course have developed soft skills, such as communication skills, team spirit, organizational ability, analytical thinking, problem-solving capability, and leadership skills. Therefore, various parties must fully support the implementation of the learning contract.

\section{Method}

This study uses literature review and survey to obtain data. After analyzing the theories and opinions in previous studies, we conducted a survey to obtain feedback from respondents who provided the actual situation of using learning contracts. All statements in the instrument developed from existing literatures that sourced from the literature review section.

This research conducted an extensive literature review that covered previous studies from within and outside Malaysia. Research on learning contracts conducted in Malaysia was generally limited compared with the research conducted abroad. This finding indicated that the usage of a learning contract is still at its infancy and has yet to be explored in Malaysia. Therefore, this study obtained several of its references from foreign literature.

Questionnaires were distributed to obtain data on the actual situation of learning contracts in UKM. This survey targeted UKM students who have completed the eight credit hours of HHHC9118-Soft Skills course. These students have conducted projects or activities based on their learning contract. The data is collected during the briefing session about the course (HHHC9118) at every residential college. This is to ensure the students respond to the survey diligently and at real time. The survey form is handed over by the students to researcher once it is being completed.

The required information was collected through the questionnaire, which had two parts. The first part asked for the background of the respondents, while the second part asked about their levels of self-esteem after completing the program. The first part collected important information, such as gender, residential college, and faculty. The second part consisted of 10 statements that can be either positive or negative. The students were required to choose an answer based on a 1 to 5 Likert scale (1 means "Strongly Disagree," and 5 means "Strongly Agree"). The feedback for each statement is interpreted to understand the true meaning of the respondents. Table 1 shows the interpretation of the respondents for each statement.

Table 1. Interpretation of statements

\begin{tabular}{ccc}
\hline Statement Type & Agreement & Interpretation \\
\hline Positive & Positive & Positive \\
Positive & Negative & Negative \\
Negative & Positive & Negative \\
\hline
\end{tabular}

According to Table 1, when the statement and the agreement are both positive, the statement was interpreted as positive. However, if a positive statement received a negative response, the statement was negative. The 
interpretation was negative if a negative statement received a positive response. If a negative statement received a negative response, the statement was positive. The positive interpretations were given one point, whereas negative interpretations did not receive any points. These points determined the success of the program.

Overall, 2,378 respondents participated in the survey. Feedback was analyzed using the Statistical Package for Social Sciences (SPSS) software. The analysis results are presented in the next Tables.

\section{Result and Discussion}

\subsection{Background of Respondents}

The survey was conducted among UKM students who have completed the course, HHHC9118-Soft Development. First analysis is to determine the reliability of the data via Cronbach's Alpha analysis. All 10 statements are combined together and analyzed, giving the Cronbach's Alpha value of 0.876 . This can be treated as good reliability of data is achieved, as the reading is more than 0.7 . For timing, the students take about 10 minutes to complete the survey form. The time taken is sufficient, since the briefing session allocate about 15 minutes (after briefing) as a direction to complete the survey form.

Table 2. Number of students based on gender

\begin{tabular}{ccccc}
\hline No. & Gender & Frequency & Percentage (\%) & Cumulative Percentage (\%) \\
\hline 1 & Male & 657 & 27.60 & 27.60 \\
2 & Female & 1721 & 72.40 & 100.00 \\
& Total & $\mathbf{2 3 7 8}$ & $\mathbf{1 0 0 . 0 0}$ & $\mathbf{1 0 0 . 0 0}$ \\
\hline
\end{tabular}

Table 2 shows the number of respondents based on gender. The percentage of female respondents is $72.40 \%$, whereas the percentage of male respondents is $27.60 \%$. These figures indicate that the majority of the respondents are women. The respondents were also divided based on their Faculty. Table 3 shows the number and percentage of respondents in each faculty.

Table 3. Number of respondents from each faculty

\begin{tabular}{lcccc}
\hline No. & Faculty & Frequency & Percentage (\%) & Cumulative Percentage \\
\hline 1 & Faculty of Islamic Studies (FIS) & 204 & 8.60 & 8.60 \\
2 & Faculty of Social Sciences and Humanities (FSSH) & 352 & 14.80 & 23.40 \\
3 & Faculty of Economics and Business (FEB) & 370 & 15.60 & 38.90 \\
4 & Faculty of Medicine (FMED) & 226 & 9.50 & 48.40 \\
5 & Faculty of Science and Technology (FST) & 393 & 16.50 & 65.00 \\
6 & Faculty of Education (FED) & 90 & 3.80 & 68.80 \\
7 & Faculty of Engineering and Built Environment (FEBE) & 198 & 8.30 & 77.10 \\
8 & Faculty of Pharmacy (FPHAR) & 86 & 3.60 & 80.70 \\
9 & Faculty of Information Sciences and Technology (FIST) & 160 & 6.70 & 87.40 \\
10 & Faculty of Law (FLAW) & 63 & 2.60 & 90.10 \\
11 & Faculty of Dentistry (FDENT) & 49 & 2.10 & 92.10 \\
12 & Faculty of Health Sciences (FHS) & 187 & 7.90 & 100.00 \\
\hline & Total & $\mathbf{2 3 7 8}$ & $\mathbf{1 0 0 . 0 0}$ & $\mathbf{1 0 0 . 0 0}$ \\
\hline
\end{tabular}

Table 3 shows 12 faculties in the university. Each faculty has a different number of respondents. Most of the respondents (393 students) are from FST (16.50\%), which was followed by FEB with 370 students $(15.60 \%)$, and FSSH with 352 students (14.80\%). FDENT had the lowest number (49 students) of respondents $(2.10 \%)$. The background of the respondents from residential colleges was also investigated. Table 4 shows the number and percentage of respondents from each residential college. 
Table 4. Number of respondents from each residential college

\begin{tabular}{lcccc}
\hline No. & Residential College & Frequency & Percentage (\%) & $\begin{array}{c}\text { Cumulative } \\
\text { Percentage }\end{array}$ \\
\hline 1 & Dato' Onn Residential College (DORC) & 116 & 4.90 & 4.90 \\
2 & Tun Hussien Onn Residential College (THORC) & 147 & 6.20 & 11.10 \\
3 & Aminuddin Baki Residential College (ABRC) & 190 & 8.00 & 19.00 \\
4 & Ungku Omar Residential College (UORC) & 145 & 6.10 & 25.10 \\
5 & Ibrahim Yaacob Residential College (IYRC) & 158 & 6.60 & 31.80 \\
6 & Burhanuddin Helmi Residential College (BHRC) & 155 & 6.50 & 38.30 \\
7 & Rahim Kajai Residential College (RKRC) & 138 & 5.80 & 44.10 \\
8 & Ibu Zain Residential College (IZRC) & 81 & 3.40 & 47.50 \\
9 & Keris Mas Residential College (KMRC) & 479 & 20.10 & 67.70 \\
10 & Pendeta Za'aba Residential College (PZRC) & 246 & 10.30 & 78.00 \\
11 & Tun Dr. Ismail Residential College (TDIRC) & 33 & 1.40 & 79.40 \\
12 & Tun Syed Nasir Residential College (TSNRC) & 490 & 20.60 & 100.00 \\
\hline & Total & $\mathbf{2 3 7 8}$ & $\mathbf{1 0 0 . 0 0}$ & $\mathbf{1 0 0 . 0 0}$ \\
\hline
\end{tabular}

Table 4 shows the number and percentage of respondents who are based on their residential colleges. UKM has 12 residential colleges. TSNRC had the highest number of students with 490 respondents $(20.60 \%)$, which was followed by the KMRC with 479 respondents $(20.10 \%)$, and PZRC with 246 respondents (10.30\%). TDIRC had the lowest number of students, with 33 respondents $(1.40 \%)$.

This survey represented all UKM students according to gender, faculty, and residential college. The faculties and residential colleges differed in their number of respondents, and different student capacities. Therefore, the backgrounds of the respondents were adequately covered, and our survey has produced acceptable results.

\subsection{Self-Esteem Level of Respondents}

The levels of the self-esteem of students are discussed in this section. The second part of the questionnaire contained 10 statements that were either negative or positive. Analytical methods are described in the research methodology section. Table 5 shows the analysis results. 
Table 5. Level of self-esteem after completing the course

\begin{tabular}{|c|c|c|c|c|c|c|c|}
\hline \multirow{2}{*}{ No. } & \multirow{2}{*}{ Statement } & \multirow{2}{*}{$\begin{array}{c}\text { Type of } \\
\text { Statement }\end{array}$} & \multicolumn{2}{|c|}{ Agreement (\%) } & \multirow{2}{*}{$\begin{array}{l}\text { Majority } \\
\text { Result }\end{array}$} & \multirow{2}{*}{ Interpretation } & \multirow{2}{*}{ Mark } \\
\hline & & & Positive & Negative & & & \\
\hline 1 & $\begin{array}{l}\text { In general, I am satisfied } \\
\text { with myself. }\end{array}$ & Positive & 76.9 & 23.1 & Positive & Positive & 1 \\
\hline 2 & $\begin{array}{l}\text { Sometimes, I feel that I'm } \\
\text { not good at all. }\end{array}$ & Negative & 37.7 & 62.3 & Negative & Positive & 1 \\
\hline 3 & $\begin{array}{l}\text { I think I have a good quality } \\
\text { of characteristics. }\end{array}$ & Positive & 89.0 & 11.0 & Positive & Positive & 1 \\
\hline 4 & $\begin{array}{c}\text { I can do what is done by } \\
\text { others. }\end{array}$ & Positive & 84.3 & 15.7 & Positive & Positive & 1 \\
\hline 5 & $\begin{array}{l}\text { I think there is nothing to be } \\
\text { proud of myself. }\end{array}$ & Negative & 16.2 & 83.8 & Negative & Positive & 1 \\
\hline 6 & Sometimes, I feel useless. & Negative & 25.8 & 74.2 & Negative & Positive & 1 \\
\hline 7 & $\begin{array}{l}\text { I felt myself important, just } \\
\text { like everyone else. }\end{array}$ & Positive & 90.0 & 10.0 & Positive & Positive & 1 \\
\hline 8 & $\begin{array}{l}\text { I wish I would have more } \\
\text { respect for myself. }\end{array}$ & Positive & 94.3 & 5.7 & Positive & Positive & 1 \\
\hline 9 & $\begin{array}{l}\text { Overall, I guess I'm a } \\
\text { failure. }\end{array}$ & Negative & 5.5 & 94.5 & Negative & Positive & 1 \\
\hline 10 & $\begin{array}{l}\text { I have a positive attitude } \\
\text { toward myself. }\end{array}$ & Positive & 93.0 & 7.0 & Positive & Positive & 1 \\
\hline \multicolumn{7}{|c|}{ Total Mark } & 10 \\
\hline
\end{tabular}

The first statement, "I am satisfied with myself," is positive as $76.9 \%$ of the respondents gave a positive feedback to this statement, compared to $23.1 \%$ of the respondents who gave a negative feedback. Because the student feedback is interpreted as positive, the first statement is scored 1 . This result suggests that the course on learning contracts has increased the satisfaction of students with themselves.

In the second statement, a negative statement is used as the second question. Responses to "Sometimes, I feel that I'm not good at all" indicate $62.3 \%$ of respondents gave a negative agreement against $37.7 \%$ who agreed. This finding gives a positive interpretation when the majority of students do not agree with a negative statement. Thus, the score obtained for the second question is 1 . These results indicate that the majority of the students felt better after undergoing a course in learning contract.

The third statement is interpreted as positive and given 1 point. Majority of the respondents $(89.0 \%)$ positively responded to the statement, "I think I have good quality characteristics," compared to $11.0 \%$ of the respondents who negatively responded. This result showed that students improved their characteristics after completing the course.

The fourth statement, "I can do what is done by others" is positive as indicated in the $84.3 \%$ of the respondents agreeing with this statement. By contrast, $15.7 \%$ of the respondents viewed this statement negatively. Therefore, this statement is interpreted as positive and given 1 point. Majority of the students felt they could do what other people can after completing this course.

The fifth statement, "I think there is nothing to be proud of myself," is a negative statement. From the respondents, $83.8 \%$ viewed this statement negatively, while $16.2 \%$ deemed it positively. The negative feedback to this item indicated a positive interpretation of the statement. Therefore, this statement received 1 point. The results showed that the students were encouraged to accomplish things they could be proud of after completing the course.

The sixth statement, "Sometimes, I feel useless," is negative. Around $74.2 \%$ of the respondents disagreed with this statement, and $25.8 \%$ of the respondents agreed. Therefore, this statement is interpreted as positive, and given 1 point. This result showed that the course boosted the self-confidence and self-value of the respondents. 
The seventh statement, "I felt myself important, just like everyone else." is given a positive interpretation and 1 point. Majority of the respondents at $90.0 \%$ agreed with this positive statement, compared to $10.0 \%$ of the respondents who disagreed. This result indicated students felt they were important just like everyone else and those they are needed in the community after completing the course.

The eighth statement, "I wish I would have more respect for myself," is positive and received positive feedback from $94.3 \%$ of the respondents. Only $5.7 \%$ of the respondents have expressed different opinions. This statement is given 1 point because it was given positive interpretation. This result showed that the course in learning contract has boosted the self-respect of students.

The ninth statement, "Overall, I guess I'm a failure," is negative. Around $94.5 \%$ of the respondents disagreed with this statement, whereas $5.5 \%$ agreed. This finding showed that majority of the students responded negatively to this negative statement. This situation received a positive interpretation and 1 point. A very high percentage indicated that the learning contract course had successfully trained the students in carrying out a project and in becoming successful individuals.

The tenth statement, "I have a positive attitude toward myself," is positive. A high percentage of respondents at $93.0 \%$ agreed with this statement, compared to $7.0 \%$ of the students who disagreed. Therefore, this statement is given a positive interpretation and 1 point. This result indicated that the course in learning contract motivated students to view themselves positively by accomplishing their assignments.

The interpretations of these statements obtained a total score of 10. Each statement was awarded 1 point after the positive interpretation of the respondents. The total score indicated that the course in learning contract has significantly influenced the soft skills of students. Moreover, the percentage of positive feedback is considered as very good when it falls between $74.2 \%$ and $94.5 \%$. This result indicate that the approach of learning contract successful to increase the soft skill of UKM's students who have completed the course.

The learning contract has been proven to help in improving the soft skills of university students. Even though this is a first cohort of UKM's student, the result shows a very positive impact of this approach on the students. When the first batch is completed, it shows that learning contract is increase in their self esteem. There are also students that actively involved in various co-curriculum activities that exceed 8 credit hours and at the same time excellent in their academic performance. The results from the survey analysis supported the theories of previous researchers about the advantages and effectiveness of the learning contract in the learning systems of universities.

The concept of learning contract provides flexibility to the students to perform the selected activities. Students are able to choose activities of their interest to expand their creativity and motivate themselves to perform the activities. This approach can enhance students' ability to manage the activities and provide the best platform for them to gain experience and skills for working life. These experiences and skills can not be gain through learning and teaching activities in the classroom alone. Therefore, the learning contract is a complement of normal learning in classroom to develop students who have the necessary skills to be a quality employee.

This approach should be a new mechanism in developing soft skill of students. Previously, many parties within UKM assumed that the soft skill is embedded in academic curriculum. However, this assumption sometimes cannot be clearly judge. Therefore, the implementation of this approach must be continued to produce more graduates with excellent soft skills. In the effort to improve current situation of soft skill among the student, a structured approach is needed where the student is given 8 credit hours for their activities. However, the existing modules must be improved to achieve better results. The experiences of the first cohort of students can be used as a benchmarking in restructuring the module improvement for the course in learning contracts at UKM. This can be a new knowledge about the effect of learning contract to UKM learning environment.

\section{Conclusion}

Fresh graduates use their soft skills as their weapons in the intensely competitive job market to grab better job opportunities. The academic achievements alone cannot save a graduate from failing in his or her industry because employers expect employees to contribute to the success of the organization through their skills. Moreover, candidates with excellent soft skills tend to be selected by the employer for the job.

The effectiveness of learning contracts in improving the soft skills of students has been recognized worldwide for many years. Therefore, UKM has taken the right step by using learning contracts to improve the soft skills of students. All the aspects of the learning contracts have received encouraging feedback from several studies, which indicates that the HHHC9118-Soft Skills course has managed to enhance the soft skills of students.

Therefore, the implementation of learning contracts in the university must be continued as it can enhance the soft 
skills of students. Nevertheless, further research must be conducted to assess and to fix the flaws of the existing modules. Learning contracts have satisfied the students by improving their soft skills. Future research needs to focus on the system and mechanism of the implementation of learning contracts.

\section{References}

Anderson, G., Boud D., \& Sampson, J. (1994). Expectations of quality in the use of learning contracts. Retrieved June 10, 2002, from http://www.lle.mdx.ac.uk/hec/journal/1-1/2-1.htm

Boak, G. (1998). A complete guide to learning contracts. Hampshire, England: Gower Publishing, Ltd.

Bogo, M., \& Vayda, E. (1998). The practice of field instruction in social work: Theory and process (2nd ed.). New York: Columbia University Press.

Brecko, D. (2003). Learning contract: A new tool for managing knowledge. Knowledge Society-Challenges to Management Globalisation, Regionalism and EU Enlargement Process Proceedings of the 4th International Conference of the Faculty of Management Koper, University of Primorska. 20-22th November, 2003.

Brewer, G., Williams, A. \& Sher, W. (2007). Utilising Learning Contracts to Stimulate Student Ownership of Learning. Proceedings of the 2007 AaeE Conference, Melbourne.

Brockett, R. G., \& Hiemstra, R. (1991). Self-Direction in Adult Learning: Perspectives on Theory, Research, and Practice. Routledge Series on Theory and Practice of Adult Education in North America (pp. 100-145). San Francisco, CA: Jossey-Bass Inc.

Canham, J., \& Bennett, J. (2002). Mentorship in community nursing: Challenges and opportunities. United Kingdom: Blackwell Science.

Chickering, A. W., \& Gamson, Z. F. (1991). Applying the Seven Principles for Good Practice in Undergraduate Education. New Directions for Teaching and Learning. Number 47, Fall 1991. San Francisco: Jossey-Bass Inc.

Cross, V. (1996). Introducing learning contracts into physiotherapy clinical education. Physiotherapy, 82(1), 21-27. http://dx.doi.org/10.1016/S0031-9406(05)66993-3

Freedberg, S. (1989). Self determination: Historical perspectives and effects on current practice. Social Work, 34(1), 33-38.

Hardigan, P. (1994). Investigation of learning contracts in pharmaceutical education. American Journal of Pharmaceutical Education, 58, 386-390.

Hermens, A., \& Clarke, E. (2009). Integrating blended teaching and learning to enhance graduate attributes. Journal of Education and Training, 51(5/6), 476-490. http://dx.doi.org/10.1108/00400910910987264

Horejsi, C. R., \& Garthwait, C. L. (2002). The social work practicum: A guide and workbook for students. Boston: Allyn \& Bacon.

Hussain, O., Berhannudin, M. S., Dawilah, A. S. M., \& Abdullah, S. (2008). Pelaksanaan Pendekatan Pembelajaran Berasaskan Pengalaman (PBM dan PBMBP) Bagi Meningkatkan Kemahiran Insaniah Pelajar. Journal of Human Capital Development, 1(1), 61-73.

Johnston, B., \& Watson, A. (2004). Participation, reflection and integration for business and lifelong learning: Pedagogical challenges of the integrative studies programme at the University of Strathclyde Business School. Journal of Workplace Learning, 16(1/2), 53-62. http://dx.doi.org/10.1108/13665620410521512

Knowles, M. S. (1986). Using Learning Contracts. San Francisco, CA: Jossey Bass.

Knowles, M. S. (1990). The Adult Learning: A Neglected Species (4th ed.). Houston: Gulf Publishing Company.

Kuh, G. D., Kinzie, J., Gruce, T., Shoup, R., \& Gonyea, R. M. (2006). Connecting the Dots: Multi-Faceted Analyses of The Relationships Between Student Engagement Results From The NSSE, and The Institusional Pratices and Conditions That Foster student Success. National Survey of Student Engagement, Indiana University Center for Post Secondary Research and Planning.

Lemieux, C. M. (2001). Learning contracts in the classroom: Tools for empowerment and accountability. Journal of Social Work Education, 20(2), 263-276. http://dx.doi.org/10.1080/02615470120044347

Mahoney, J. L., Cairns, B. D., \& Farmer, T. W. (2003). Promoting interpersonal compentence and educational success through extracurricular activity participation. Journal of Educational Psycohology, 95(2), 409-418. http://dx.doi.org/10.1037/0022-0663.95.2.409 
McAllister, M. (1996). Learning contracts: An Australian experience. Nurse Education Today, 16, 199-205. http://dx.doi.org/10.1016/S0260-6917(96)80024-4

McCabe, P. P. (2008). How Learning Contracts Motivate Students. Middle School Journal, 39(5), 13.

Mulder, M., Gulikers, J., Biemans, H., \& Wesselink, R. (2009). The new competence concept in higher education: Error or enrichment? Journal of European Industrial Training, 33(8/9), 755-770. http://dx.doi.org/10.1108/03090590910993616

Neary, M. (2000). Teaching, Assessing and Evaluation for Clinical Competence: A Practical Guide for Practitioners and Teachers. Cheltenham: Nelson Thornes.

Rolfe, G. (1996). Closing the Theory-Practice Gap. Oxford: Butterworth Heinemann.

Savery, J. R., \& Duffy, T. M. (1994). Problem Based Learning: An instructional model and it's constructivist framework. In B. Wilson (Ed.), Constructivist learning environments: case studies in instructional design. Englewood Cliffs, NJ: Educational Technology Publications.

Selamat, J. H., Ismail, K. H., \& Ahmad, S. (2010). Objektif dan faedah berpersatuan. Dlm. Shahruddin Ahmad, Khaidzir Hj. Ismail \& Jumali Hj. Selamat (pnyt). Mengurus Persatuan: Proses dan Kemahiran. Bangi: Penerbit UKM.

Selamat, J. H., Ismail, K. H., Aiyub, K., Arifin, K., Mohamad, L. Z., Rajikan, R., . . Derahim, N. (2011). Penilaian Aktiviti Kokurikulum Berkredit Berasaskan Kontrak Pembelajaran di UKM. Jurnal Personalia Pelajar, 14, 101-116.

Stewart-David, W. (1993). Learning Contracts and Student Placements with Employers. In M. Laycock, \& J. Stephenson (Eds., pp. 97-104), Using Learning Contracts in Higher Education. London: Routledge.

Sweitzer, H. F., \& King, M. A. (2008). The successful internship: Personal, professional, and civic development (3rd ed.). United States: Nelson Education, Ltd.

Tornyay, R., \& Thompson, M. (1987). Strategies for Teaching Nursing (3rd ed.). Albany, NY, Delmar: A Wiley Medical Publication.

Tuohy, D., \& Bailey, M. E. (2009). Student nurses' experiences of using a learning contract as a method of assessment. Journal of Nurse Education Today, 29, 758-762. http://dx.doi.org/10.1016/j.nedt.2009.03.012

\section{Copyrights}

Copyright for this article is retained by the author(s), with first publication rights granted to the journal.

This is an open-access article distributed under the terms and conditions of the Creative Commons Attribution license (http://creativecommons.org/licenses/by/3.0/). 